\title{
Measuring and Managing Ex Ante Transaction Costs in Public Sector Contracting
}

\begin{abstract}
Transaction costs attributes, such as the complexity of the product being purchased, shape the risk that government contracts will fail. When transaction cost risks are particularly strong, a common prescription is to avoid contracting altogether, or if unavoidable, to spend additional resources on contract management activities. We present evidence on the size and variability of governments' ex ante transaction cost spending, using original data from 72 contracts issued by 47 Danish local governments. Ex ante transaction costs average 2.7 percent per contract and are relatively higher when services are more complex and lower when governments have prior contracting experience and when contracts are larger. Our analyses suggest the importance of distinguishing between transaction cost attributes and governments' choices to spend resources in response to them. Effective management spending in the face of transaction costs can help governments in organizing and capturing value from contracting with private businesses.
\end{abstract}

This is the author manuscript accepted for publication and has undergone full peer review but has not been through the copyediting, typesetting, pagination and proofreading process, which may lead to differences between this version and the Version of Record. Please cite this article as doi: $10.1111 /$ puar.13048

This article is protected by copyright. All rights reserved. 
Author Bios:

Ole Helby Petersen is a Professor (Mso) in public administration and Director of the Center for Research on Public-Private Collaboration at Roskilde University, Denmark. His research interests include public sector contracting, transaction costs, privatization, and public-private partnerships.

Erik Baekkeskov is a Senior Lecturer in Public Policy and Political Science at The University of Melbourne, Australia. His research interests include public administrative reforms and public policy-making.

Matthew Potoski is Professor at the Bren School of Environmental Science and Management, University of California, Santa Barbara. He is co-author of The Voluntary Environmentalists (Cambridge, 2006) and Complex Contracting (Cambridge 2014) and has written on a variety of topics including businesses environmental strategies, environmental policy, and public and nonprofit management.

Trevor L. Brown is Dean of the John Glenn College of Public Affairs, The Ohio State University. He conducts research and teaches on public management and leadership,

This article is protected by copyright. All rights reserved. 
governance, government contracting, public-private partnerships, and democracy and democratic transitions. 
Evidence for Practice:

- Danish local governments spend 2.7 percent of contract value on ex ante transaction cost expenditures

- Ex ante transaction cost spending varies in response to the complexity of the product, the size of the contract, government fiscal capacity, and the government's contracting experience.

- Governments' transaction cost spending reflects transaction cost attributes that influence the risk of negative contract outcomes.

This article is protected by copyright. All rights reserved. 
Governments often look to reduce costs by purchasing products and services instead of making them, under the idea that market competition among suppliers drives down prices (Sclar 2000; Van Slyke 2003). When governments purchase a product or service, part of the overall cost is the resources it expends for finding and selecting vendors, negotiating contract terms, monitoring vendor performance, and ensuring that the delivered product meets specifications, items that collectively are referred to as transaction costs (Williamson 1996). At first glance, spending motivated by transaction costs can seem wasteful - they raise total costs without directly increasing the amount or quality of the purchased product. On closer scrutiny, however, transaction cost spending can be essential for mitigating risk and ensuring that contracts produce value. For instance, without proper care in writing and monitoring a refuse collection contract, the vendor may fail to pick up garbage on a regular schedule or return bins to their proper locations. Getting the right contract terms may be even more important for products that are more complex, such as eldercare programs or information technology systems (Brown, Potoski, and Van Slyke 2010).

An important objective in contract management is to allocate resources and establish procedures to manage contract risk and improve contract value. The nature of this challenge depends on characteristics of the product and circumstances of the contract, what are sometimes called transaction cost attributes (Williamson 1979, 1991, 1996). The practice of contract management can be challenging for several reasons. First, 
unlike purchasing costs, where prices tend to be negotiated and posted, transaction cost spending can be more difficult to observe and measure. Such spending tends to be dispersed across budget categories and involves less tangible resources like time, effort, and expertise. Second, the need for transaction cost spending is highly variable across products and circumstances; the need is lower for simple products that are commonly bought and sold in robust markets, and the need is higher for complex products that must be designed and produced for the purchaser's unique requirements (Levin and Tadelis 2010). Finally, while spending on some transaction cost items is inevitable, such as specifying a refuse collection schedule, other transaction cost spending can be managed, and perhaps even reduced in some circumstances, without sacrificing value.

When academics study transaction costs in buying and selling, they tend to focus on the attributes that raise and lower what buyers and sellers should spend to execute an effective exchange (Brown and Potoski 2004; Bækkeskov 2011; Hefetz and Warner 2012; Johansson 2015). Of course, a government may not spend its resources so wisely. A government might purchase a complex service, one that would ideally require additional spending to write a detailed contract and evaluate the service after delivery, without actually spending the money for writing an effective contract and evaluating the service. There has been very little research measuring the size of governments' actual transaction cost spending, aside from a few studies on construction and infrastructure projects (Soliño and Santos 2010; Whittington 2012; De Schepper, Haezendonck, and 
Dooms 2015). And perhaps more importantly, there has been little research on whether governments adjust spending in response to transaction cost attributes that can threaten contract outcomes. ${ }^{1}$ Further knowledge of governments' actual transaction cost spending, and the attributes affecting these costs, can assist public managers in better organizing and managing contracting processes in ways that capture value (Melese et al. 2007).

In this article, we present original data on the monetary value of local governments' transaction cost spending across a range of commonly purchased services in Denmark, providing a rare perspective on their financial cost. Because of the nature of the data, we focus on expenses that occur prior to the sale, expenses that we call "ex ante transaction cost expenditures." These are costs that are additional to the direct costs of producing the product or service. The data show that ex-ante transaction cost spending varies across different services, from $0.2 \%$ of contract value for dental care services to $7.6 \%$ for information technology services. Our further analyses show that governments effectively adjust spending in response to transaction cost attributes, raising transaction cost spending when purchasing service that are more complex and lowering expenditures when the government has prior contracting experience and when making scale purchases. For research, we show how transaction cost attributes across different services lead to expenditures for managing contracting risks, while providing a rare estimate of the 
spending magnitude. For practitioners, we suggest practices for optimizing contract management spending to improve the value of contracting with businesses.

In the first section after this introduction, we identify transaction attributes - the product and market characteristics that make contracting challenging - and transaction risks associated with such attributes. We then discuss contract management instruments and activities that can mitigate these risks. Implementing management instruments to mitigate risks requires spending, the transaction cost expenditures. In the second section, we present the data on the magnitude of ex ante transaction cost spending across different product categories. In the third section, we present the data and methods for the fuller empirical analysis on potential links between transaction attributes and transaction cost spending and the fourth section presents the results. The final section concludes the article with implications for contract management practice and suggestions for future research.

\author{
Transaction Attributes, Risks, and Expenditures in Public Sector Contracting \\ Contracts do not always deliver on their promise: sometimes the products \\ governments buy are more expensive than anticipated, are delayed in arrival, or do not \\ work in the ways intended (Sclar 2000; Milward and Provan 2003; Van Slyke 2003). ${ }^{2}$ A \\ losing outcome for the purchasing government means receiving less in product value than \\ what was anticipated for the price, while a losing outcome for the vendor means
}


receiving less in compensation than the costs to produce and deliver the product. For buyers, one source of risk is making sure the products targeted for purchase provide the best value. It is not enough to simply open the phone book and call the first provider on the list. In most cases, buyers need to do some comparison shopping to find the best value product for their needs. Another risk arises when the government and vendor have different motivations for entering into an exchange (which they often have): one party may pursue its own interests, knowingly or unknowingly, at greater expense to the other party (Brown, Potoski, and Van Slyke 2016).

Both the purchaser and the vendor can take steps to mitigate contracting risks. ${ }^{3}$ Transaction risks are driven by transaction attributes, which are characteristics of products and markets (Williamson 1996). While a transaction attribute may increase contracting risk - and hence the prospects of receiving less value in the exchange - a transaction cost expenditure can counteract (i.e., help to manage) that underlying risk (Mooi and Ghosh 2010). The logic here is that transaction cost expenditures should ideally be in response to transaction risk. The contract can be written more precisely, detailing the product and delivery terms across a range of contingencies. Buyers and sellers can also coordinate investments and allocate costs, such as mutual performance monitoring systems, to ensure the contract delivers the greatest gains for both parties. Viewed through the lens of transaction cost analysis, contract value does not mean simply minimizing the price paid for a product. A contract's value comes from 
what the government receives minus the total contracting costs, where total costs are the sum of the price, transaction cost expenditures, and the risk of negative outcomes (Clemons, Reddi, and Row 1993: 14; Cheung 1998; Melese et al. 2007). ${ }^{4}$ Transaction cost spending only sits in the purchasing government's accounts when it actually expends funds to mitigate the underlying transaction risk, that is, when government deploys management instruments and activities that address the transaction attributes. If a purchasing government does not incur expenses to control these risks, it is more likely to incur the losses of a contract that does not live up to expectations; that is, it accepts risk arising from the attributes rather than mitigating such risk through transaction cost expenditures. Figure 1 illustrates the relationship between transaction attributes, contracting risks, and transaction cost expenditures in public sector contracting.

[Figure 1 here]

Purchasing governments incur ex ante and ex post transaction cost expenditures. Ex ante expenditures occur before the execution of the sale and include expenses for activities like searching for products and suppliers, preparing requirement specifications, evaluating bidders' offerings, and negotiating contract terms (Coase 1937; Williamson 1996; Marsh 1998; Barthélemy and Quélin 2006; Melese et al. 2007). In other words, ex ante costs are incurred to "discover who it is that one wishes to deal with, to inform 
people that one wishes to deal and on what terms, to conduct negotiations leading up to a bargain, to draw up the contract..." (Coase 1960: 15).

Ex post transaction cost expenditures are incurred after the sale is executed, and include expenses for monitoring performance and enforcing contract terms, evaluating the product or service after it has been delivered, arbitration and conflict resolution, and re-negotiating the contract when circumstances require different terms. In other words, ex post transaction cost expenditures are incurred "to undertake the inspection needed to make sure that the terms of the contract are being observed, and so on" (Coase 1960: 15). Table 1 provides examples of managing, planning and coordinating activities and instruments that constitute ex ante and ex post transaction cost expenditures in government contracting.

[Table 1 here]

An example can help illustrate the differences among transaction attributes, contracting risks, and transaction cost expenditures. Imagine that a government wanted to buy a relatively unique product, like a highly customized information technology system. Such purchases have several transaction attributes: uncertainty about product characteristics, and highly specialized investments to customize the product to the purchasing government's needs. These transaction attributes can favor the vendor since 
the purchasing government has limited ability to evaluate the product's quality, and once the exchange begins, the specialized investments may lock the government into purchasing from just one vendor. Such transaction attributes increase the risk that the purchasing government would be unable to respond should the seller cut corners or raise prices.

A common strategy for reducing the risk of a negative contract outcome in such circumstances is to screen potential vendors to identify those with a reputation for delivering value. Such research is a transaction cost expenditure because the government is spending money for its staff's time and effort. However, we can consider another scenario in which the government entered the contract without performing the extra background research on the vendors. While forgoing such research may seem ill-advised (Barthélemy 2001; Mooi and Ghosh 2010), one can imagine at least hypothetical circumstances in which it might make sense. The government might have a higher risk tolerance for the contract, it might not have the resources to conduct a more complete search, or perhaps it did not have much confidence that its research efforts would turn up much useful information. If the government chose this path, it would incur no transaction cost expenditures, but the transaction attributes and their accompanying contracting risks would remain.

Effectively allocating transaction cost expenditures relative to production costs, returns, and risk can be a complicated calculus, influenced by a myriad of transaction 
attributes particular to the exchange, such as characteristics of the product being purchased, qualities of the buyer and seller, and market conditions (for an overview see Bel, Fageda, and Warner 2010; Levin and Tadelis 2010). ${ }^{5}$ Below we present some of the more prominent categories of transaction attributes and how they can influence transaction cost spending. A few caveats are in order. The discussion focuses more on ex ante transaction costs - ex post data unavailable to us - and describes relatively simple and direct transaction attributes. A more complete treatment would include more of the dynamics and interactions inherent in how transaction attributes influence spending and contract outcomes in different settings. One type of transaction cost spending may lower the need for another, and this effect may vary depending on what is being purchased. For example, carefully selecting high quality vendors may reduce the need for writing a detailed contract for some products but not for others. Such a treatment, however, is beyond what our data can support, and inquiry into such phenomena belongs to the domain of future research (see the final section for a discussion).

Product Complexity: Contract management practices need to reflect the characteristics of the product to be purchased. Product characteristics can be an important transaction attribute. Complex products, such as welfare services, are inherently more difficult to describe in advance of purchase (i.e., high uncertainty), can require specialized investments tailored to the seller's specifications (i.e., high asset specificity), and are often offered in markets with few buyers and sellers (Girth et al. 2012). These 
attributes mean that they come with higher contracting risks, which encourages transaction cost spending, such as writing more detailed and intricate contract terms or purchasing insurance or guarantees. Simple products, like office supplies, are easy to describe in detail or are available in more standardized and commoditized forms (i.e., lower uncertainty). Markets for such products are typically more robust, with many buyers and sellers making frequent exchanges for different versions of similar products (i.e., lower asset specificity and higher frequency of exchanges). These product and market characteristics tend to lower the need to incur in transaction cost expenditures since the risk of negative outcomes is lower. Taken together, this argument leads to our first hypothesis.

Hypothesis 1: Contracting governments are more likely to incur transaction cost expenditures for complex products than simple products, all other factors equal.

Management and Fiscal Capacity: Governments' management and fiscal capacity are transaction attributes that can influence their transaction cost expenditures. Stronger fiscal capacity creates the opportunity to undertake additional expenditures on specific contract management instruments. And absent core investments in management personnel, governments may lack the ability to prepare and complete a tender in a way that maximizes public value (e.g., by taking full advantage of available market 
competition or minimizing uncertainty). Effective use of contract management activities and instruments can mitigate risks arising from transaction attributes (Lawther 2002; Joaquin and Greitens 2012). Examples are writing requests for proposals, creating a system to evaluate proposals, and monitoring the vendor's performance. Just as governments make investments in managing direct service delivery, governments can likewise invest in their administrative capacity to manage contract service delivery (Brown and Potoski 2003; Romzek and Johnston 2002). This generally means hiring and training administrative, legal, and managerial staff to serve as purchasers, contract drafters, contract specialists, contract managers, and contract enforcers. In turn, such hiring is costly and limited by fiscal capacity. Hence, our second hypothesis is about capacity.

Hypothesis 2: Contracting governments with higher management and fiscal capacities are more likely to have higher transaction cost expenditures than governments with lower management and fiscal capacity, all other factors equal.

Contract Management Experience: Purchasing governments may also be able to reduce transaction cost expenditures by harnessing the lessons of past contracting efforts (Langlois 1992; Mayer and Argyres 2004). Experience with contracting can lower transaction cost expenditures in several ways. Experienced managers are more efficient, 
can more effectively identify where to invest transaction cost spending, and know more about different vendors and their reliability, prices, and product quality. Experience with contracting can lower the cost of writing contracts because the purchasing government can draw on proven approaches, and even contract language, from previous contracts for similar purchases. Experienced managers can even resuscitate failing markets by recruiting new sellers to ensure sufficient competition and lower overall prices (Girth et al. 2012; Johnston and Girth 2012). The lessons of experience are likely to be more impactful when repeating a purchase for the same product; tacit knowledge and standard operating procedures are more likely to transfer over time for the same product than across different types of products. ${ }^{6}$ Our third hypothesis focuses on the impact of experience.

Hypothesis 3: Contracting experience lowers transaction cost expenditures, all other factors equal.

Contract Value: Purchasing governments may also be able to reduce transaction cost spending by buying at scale (Lyons 1995). When going to the market, governments need to incur basic ex ante transaction cost expenditures, such as writing requests for proposals, soliciting and reviewing bids, and reviewing proposals before negotiating contract terms. Some of these contract preparation and management activities are 
necessary regardless of the size of purchase. For instance, the basic ex ante transaction cost expenditures for a large cleaning contract may be almost identical to a small cleaning contract, the main difference being the size of the space to be cleaned rather than the types and number of activities described in the request for proposals. By making scale purchases, governments may be able to spread one-time ex ante transaction cost expenditures across larger quantities of products and thereby reduce the transaction cost spending per unit of the product (Karjalainen 2011). Our fourth hypothesis focuses on the impact of contract value.

Hypothesis 4: Contracting governments are likely to have relatively smaller transaction cost expenditures for large contract values, all other factors equal.

\section{The Size of Ex Ante Transaction Cost Spending}

Given the importance of transaction cost expenditures for the success or failure of contracts, it is somewhat surprising that there is scant information on how much governments are actually spending. We focus here on direct ex ante transaction costs given that this is where our data lie, and we believe that this provides an important first step for understanding actual transaction cost spending. Figure 2 presents data on Danish 
local governments' ex ante transaction cost expenditures for 72 contracts across a range of product categories.

The data in Figure 2 are from a database of contracts from Local Governments Denmark - a non-profit organization owned by the 98 municipalities in the country - and the Danish central government (see Appendix 1 for further description of the data). When registering a contract in the database, Danish local government officials also provided information about the contract value and the exact amount of salary and external expenses their government spent to prepare the tender, identify vendors, negotiate terms, and sign the final contract. Our dataset contains information for all local government contracts in the database for which the purchasing authority was able to report the contract value and the precise monetary expenditure on ex ante transaction costs. The data set of 72 contracts is reported by 47 different local governments. ${ }^{7}$ These data do appear to provide a useful portrait of transaction cost spending among local Danish governments; other countries, where conditions such as contracting regulations and market contexts differ, may produce different results.

To measure ex ante transaction cost expenditures, we total all the pre-contract award expenditures identified in the entries in the database for each contract record. This method produces a data set of governments' ex ante transaction cost expenditures, which to the best of our knowledge represents the first internationally published analysis of the 
actual transaction costs expenditures across a broad portfolio of products and services that local governments commonly purchase.

We calculate the percentage that ex ante transaction costs comprised of the total spending for each contract, following the approach of Whittington (2008) and Li et al. (2013). By using a percentage of the total contract value, we obtain a standardized measure of transaction cost expenditure relative to contract size that allows us to examine transaction costs across contracts with variable total awards. For example, ex ante transaction cost spending of $\$ 50,000$ for a contract where the government spent $\$ 1,000,000$ thus represents transaction cost spending equal to 5 percent of the contract. This expenditure is in addition to the price paid to the vendor - in Williamson's (1979, 1996) terminology the production costs - and are costs associated with purchasing from external providers (the "buy" option). Importantly, this measure includes both internal and external spending, thereby providing a comprehensive account of governments' monetary ex ante transaction cost expenditure for the sample of contracts.

Figure 2 reports governments' spending on ex ante transaction costs as a percentage of the contract value from 72 contracts across 22 product categories ranging from the purchase of standardized services like refuse collection to customized products such as information technology systems. Figure 2 shows that ex ante transaction cost spending varies considerably across the service categories, from a low of 0.2 percent for dental care services (for which a highly standardized private market already exists) to a 
high of 7.6 percent for information technology programs. The average level of ex ante transaction cost spending was approximately 2.7 percent of the total contract value. Clearly, in some circumstances, ex ante transaction cost spending can have a big impact on governments' budgets.

Of course, transaction cost spending may vary across and within these service types in ways that reflect the different types of underlying transaction cost attributes, stemming from the nature of the exchange or from a mismatch between the governance arrangements for the transaction and those attributes. The next section explores whether governments adjust ex ante transaction cost spending in response to transaction cost attributes that influence contracting risk.

[Figure 2 here]

\section{Methods and Data}

To assess the impact of product complexity, management and fiscal capacity, and governments' contracting experience on transaction cost expenditures we turn again to our sample of public purchases by local governments in Denmark. The data contains information about the monetary value of governments' ex ante transaction cost expenditures in contracts involving a range of commonly purchased services. This section 
describes the data set and specifies how we operationalize the dependent and independent variables in our analysis.

We conduct a multi-variate analysis of the impact of key independent variables and controls on local government ex ante transaction cost expenditures, our dependent variable. We use fractional logit regression to account for the fact that the dependent variable measures government's ex-ante transaction costs as a percentage (fraction) of the total contract value (Papke and Wooldridge 1996; Ramalho, Ramalho, and Coelho 2018). ${ }^{8}$ Fractional logit regression has a non-linear functional form and uses Bernoulli quasi-maximum estimation to compute the conditional effect of the independent and control variables on the dependent variable (Villadsen and Wulf 2018). The fractional approach does not assume normal distribution of the data and allows us to calculate effect sizes in the same percentage point scale as our dependent variable, as discussed below.

Denmark serves as an informative setting for investigating contracting and transaction cost expenditures because all local governments in Denmark have contracting authority for a broad range of public services like refuse collection, road and park maintenance, solid waste treatment, job training, care of the elderly, information technology systems and much more (Petersen, Houlberg, and Christensen 2015). Danish municipalities have a high degree of autonomy and can choose to invest resources in procurement expertise, administrative capacity, and other skills, as they wish. Public purchasing is at the same time subject to a set of standardized European Union (EU) 
procurement directives converted into national procurement law, which requires that municipalities follow uniform procedures for the purchase of similar products.

Differences in transaction costs expenditures are thus likely to depend on contracting experience, management competencies, and product complexity, rather than differences in the legal procedures of public purchasing within and across the EU countries.

\section{Dependent Variable}

Since our goal is to understand drivers of transaction cost spending across a sample of contracts with variable total awards, our dependent variable is the ex ante transaction cost expenditures reported in Figure 2. The dependent variable is a continuous variable specified as governments' ex ante transaction cost expenditures divided by the contract value multiplied by 100 percent. The variable is based on exact information about governments' monetary transaction cost expenditure and the value of each contract (see Appendix 1 for further details). The measure includes internal as well as external transaction cost expenditures. Internal expenses are the sum of hours used by internal staff multiplied by hourly wages, whereas external expenses relate to the use of hired consultants such as legal and financial advisors or firms specialized in contracting of specific services. The dependent variable thus measures the sum of internal and external activities that make up governments' ex ante transaction costs relative to the value of the contract award in our sample of 72 local government contracts. 


\section{Independent and Control Variables}

We measure three categories of independent variables - product complexity, management and fiscal capacity, and contract management experience. We describe the operationalization of each of these constructs below.

Product Complexity: Product complexity measures the degree to which underlying transaction attributes are present for a product category. Following the approach of other public sector contracting scholars (e.g. Levin and Tadelis 2010; Hefetz and Warner 2012), we surveyed 42 Danish local contract managers (response rate 72.5 per cent) asking them to assess the contracting difficulty of 22 product categories on a five-point scale ranging from "very easy" to "very difficult" (see Appendix 2 for question wording). Products with ratings closer to 5 are more complex to specify, and those with ratings closer to 1 are less complex. As per Hypothesis 1 , the expectations is that governments will spend more on ex ante transaction cost expenditures when product complexity is higher.

Management and Fiscal Capacity: We measure the management and fiscal capacity of the contracting government with two variables. Management capacity is the number of administrative staff and managers per 1,000 inhabitants in the municipality. Fiscal 
capacity is the total tax base of the municipality in Kroner per inhabitant. As per Hypothesis 2, the expectation is that governments with more management capacity and fiscal capacity will spend more on ex ante transaction cost expenditures.

Contract Management Experience: Two variables measure government's experience with contract management. First, contract management experience is a dummy variable, scored 1 if the government has contracted for the same product before, and 0 otherwise. Second, Government contracting percentage is a continuous variable measuring the local government's overall purchasing from private providers as a proportion of the government's total expenditures on goods and services provided to citizens. This variable measures the degree to which the purchasing government engages in contracting across all products it delivers to citizens. As per Hypothesis 3, the expectation is that governments with greater contract management experience will have lower transaction cost expenditures.

Contract value is measured using the value in Kroner of each contract in our sample. As per Hypothesis 4, the expectation is that governments with greater contract values will have lower transaction cost expenditures. 
Finally, we include the variable population to control for the size of contracting units. Population is operationalized as the number of residents in the government's jurisdiction in thousands. Table 2 provides the descriptive statistics for the dependent, independent and control variables. Correlations are shown in Appendix 3.

[Table 2 here]

\section{Results}

Table 3 displays the results of our fractional regression of factors influencing local governments' ex ante transaction cost expenditures. To ease the interpretation of the substantial effects of the coefficients in our multivariate regression analysis, we transform the coefficients into Average Marginal Effects indicating the percentage-point change in the dependent variable from a one-unit increase in each of our independent and control variables. ${ }^{9}$

Consistent with hypothesis 1 , ex ante transaction cost expenditures are higher when products are more complex. A one-point increase on the five-point product complexity scale ranging from "very easy" to "very difficult" is associated with a 1.51 percentage point increase in ex ante transaction cost expenditures, holding constant the effects of other variables. For a sense of scale, recall that the average ex ante transaction cost spending is 2.66 percent of the purchase price. Thus, a one unit increase in product 
complexity results in more than one and a half times higher government spending on ex ante transaction costs.. Danish local governments significantly increase their spending on contract management to mitigate underlying transaction cost risks for more complex products.

[Table 3 here]

The coefficient for fiscal capacity per capita is positive and significant at the 0.05 level, suggesting that Danish local governments with stronger fiscal capacity are more likely to devote additional resources to managing transaction cost risks than those local governments with limited capacity. A one thousand Danish Kroner increase in the variable fiscal capacity results in a 0.06 percentage point increase in ex ante transaction cost expenditures, holding constant the effects of other variables (1 US dollar = app. 6.5 DKK). A one thousand DKK increase in fiscal capacity is thus associated with a relatively modest increase in ex ante transaction cost spending (recall that on average governments spend 2.66 percent of the contract value on ex ante transaction costs). The coefficient for management capacity per capita is not statistically significant, contrary to hypothesis 2 .

The coefficient for the variable prior contracting experience is negative and significant at the 0.001 level, thus supporting hypothesis 3. Danish local governments 
that have contracted for the same product before spend about 1.89 percentage points less on ex ante transaction costs than governments that have not contracted for the same product in the past, holding constant the effects of other variables. This suggests that experience generates significant efficiencies in contract management; transaction cost expenditures are on average reduced by more than two-thirds when governments have contracted for the same product before. The coefficient for government contracting percentage, which expresses governments' overall experience of contracting for all categories of products, is not significant, contrary to our expectations. While product specific experience seems to be associated with significant transaction costs efficiencies, general contracting experience is not.

Concerning hypothesis 4 , the coefficient for contract value is negative and significant at the 0.001 level, suggesting that ex ante transaction cost spending is lower for higher value contracts. A one million DKK increase in the variable contract value results in a 0.08 percentage point decrease in governments' ex ante transaction cost expenditures. A plausible interpretation of this finding is that there are economies of scale from investments in contract management capacity; contracts for larger amounts of the same product may require the same (or only slightly larger) contract management investments as contracts for smaller amounts of that product. Finally, the control for population is not significant. 


\section{Discussion and Conclusion: Strategies for managing transaction cost expenditures in public contracting}

In this article, we have reviewed how transaction attributes influence contracting risks and, hence, the ex ante transaction costs expenditures incurred by governments. Some ex ante expenditures are necessary to enable transactions to occur in the first place. Our analyses of actual transaction cost spending further show that ex ante transaction costs expenditures are sensitive to transaction attributes, that is, to characteristics of the goods and services being purchased and of the purchasing organization itself. Using data from 72 Danish public sector procurement transactions, we have also illustrated how such costs can increase with transactions' complexity and purchasing governments' fiscal capacity, and decrease as public buyers have experience with purchasing similar products and when purchasing at scale.

Transaction cost expenditures can be investments to reduce future transaction risks, particularly those related to unforeseen events and potential opportunism on the part of vendors. Purchasing governments have a choice between spending money early to reduce such risks, or accepting the risks and potentially great transaction costs incurred during the life of their contracts (ex post transaction costs). The transaction cost spending analyses reported in this article also have important implications for practitioners.

Harness Prior Contracting Experience: Local governments that purchased a service in the past are more likely to continue purchasing that product in the future, as 
well as to use the same delivery mode for similar types of services (Brown, Potoski, and Van Slyke 2016), suggesting that mangers learn from practice and apply that knowledge across related domains. Our research in this article provides evidence of additional learning. Danish local governments report lower ex ante transaction cost expenditures for products that they have purchased in the past, suggesting improved contracting efficiency. Importantly, our findings suggest improved contracting efficiency for governments' experience within product categories, whereas we did not find evidence of a general learning effect from government experience in general.

Leverage Fixed Transaction Cost Expenditures: Most governments invest in a set of basic ex ante transaction cost expenditures when they go to the market - writing requests for proposals, requirement specification, soliciting and reviewing bids, and reviewing proposals before negotiating contract terms. Our research shows that the ratio of ex ante transaction cost expenditures to total costs is lower for higher value contracts than for lower value contracts, suggesting that contracting spending offers economies of scale (Karjalainen 2011; Kauppi and Van Raaij 2015). One plausible interpretation is that local governments can enjoy economies in scale contract management by either bundling similar purchases into one contract or adding extensions and options to an existing contract.

Invest in Contract Management Capacity: Among scholars, diminished contract management capacity has been a cause for concern (Joaquin and Greitens 2012, Milward 
and Provan's 1993, 2000). Our study extends this research by demonstrating that those governments that have higher levels of financial capacity - "solid" governments in Milward and Provan's $(1993,2000)$ terms - are better positioned to incur ex ante transaction cost expenditures that actually do mitigate contracting risks than are "hollow" governments. While we find little support for the importance of management capacity on its own in our data, the substantive and statistically significant negative relationship between contract value and transaction cost expenditures strongly suggests positive scale effects that may be related to management. The lesson for local governments is that contracting may be the means to achieve efficiency and ultimately cost savings (Petersen, Hjelmar, and Vrangbæk 2018), but this could be contingent on investing in core administrative and management capacity.

This article also has implications for academics. It provides a rare portrait of the magnitude of ex ante transaction cost spending across a range of services. More importantly, the research shows that governments do increase transaction cost spending when transaction cost theory suggests greater risk, such as when the product is more complex and the government has no prior experience of contracting the specific product. Danish local governments have higher ex ante transaction cost expenditures when contracting for products whose transaction attributes suggest higher contracting risk. This extra effort costs resources to write the requirement specification, scan the market for potential vendors and manage the tender process - ex ante transaction cost expenditures - 
but may result in downstream cost savings as purchasing governments lower the risk of a negative contract outcome, or decrease the need for ex post expenditures on litigation or other means to resolve disputes between the purchasing government and the vendor (Brown, Potoski, and Van Slyke 2016). In addition, the analysis suggests that product complexity and experience have significant bearing on governments' ex ante transaction costs expenditures, suggesting relevance to studies using the transaction cost framework to examine government make-or-buy decisions (e.g. Levin and Tadelis 2010; Hefetz and Warner 2012; Johansson 2015).

Some important limitations of this research are also worth noting. The estimates focus on just ex ante transaction cost spending and may be somewhat imprecise because the data are self-reported based on contract managers' estimates. Moreover, the sample of 72 contracts reported by 47 of the 98 Danish local governments provides less than ideal statistical power for detecting and ruling out empirical relationships in the regression analyses. These data limitations likewise confine the empirical analyses to straightforward direct effects of transaction cost attributes on ex ante transaction cost spending. For example, the analyses are unable to identify potential interaction effects among the independent variables, which is an area for further research using larger samples of government contracts.

Our inquiry into the determinants of transaction cost expenditures suggests some directions for future research. Effective contract management identifies contracting risks 
and implements the right management instruments to mitigate them effectively and efficiently. The transaction cost framework helps identify different types of contract risk, reasons why contracts may fail to deliver win-win outcomes, such as opportunistic behavior or imprecisely defined contract terms. The framework also categorizes the attributes that create those risks, such as difficult to measure products or asset specific investment.

By distinguishing between transaction attributes, contracting risks, and transaction cost expenditures, our research raises questions about how to spend money effectively to mitigate risks. On the theoretical front, effective contract management involves understanding how to best align different contract governance arrangements with product attributes and market characteristics (Williamson 1996; Johansson, Siverbo, and Camén 2016). Scholars can contribute to this objective by more clearly mapping how specific management instruments address different types of contracting risks and transaction cost attributes. Different types of management instruments may be more or less effective at mitigating risks (Johansen and Siverbo 2011). On the empirical front, an important next step is to better identify how different management instruments perform in different contexts. For example, some procedures for evaluating vendor proposals may be more relative effective in less competitive markets while others may require market competition. Likewise, some ex ante expenditures may reduce the need for greater spending ex post, or high cost products may end up being cheaper due to lower 
transaction cost spending requirements. Such research, whether based on case studies or large samples, can then be translated into the transaction cost framework, so that insights in one setting can inform research and practice in others. 


\section{References}

Albano, Gian Luigi, and Marco Sparro. 2010. Flexible strategies for centralized public procurement. Review of Economics and Institutions 1(2): 1-32.

Baekkeskov, Erik. 2011. Issue Framing and Sector Character as Critical Parameters for Government Contracting-Out in the UK. Public Administration 89(4): 1489-1508.

Barthélemy, Jerome. 2001. The hidden costs of IT outsourcing. MIT Sloan Management Review (Spring): 60-69.

Barthélemy, Jerome, and Bertrand V. Quélin. 2006. Complexity of Outsourcing Contracts and Ex Post Transaction Costs: An Empirical Investigation. Journal of Management Studies 43(8): 1775-1797.

Bel, Germà, Xavier Fageda, and Mildred E. Warner. 2010. Is private production of public services cheaper than public production? A meta-regression analysis of solid waste and water services. Journal of Policy Analysis and Management 29(3): 553-577.

Brown, Trevor L., and Matthew Potoski. 2003. Contract Management Capacity in Municipal and County Governments Public Administration Review 63(2): 153-64.

Brown, Trevor L., and Matthew Potoski. 2004. Managing the public service market. Public Administration Review 64(6): 656-668.

Brown, Trevor, L., Matthew Potoski, and David Van Slyke. 2010. Contracting for Complex Products. Journal of Public Administration Research and Theory 20(S1): 41-58.

This article is protected by copyright. All rights reserved. 
Brown, Trevor, L., Matthew Potoski, and David Van Slyke. 2016. Managing complex contracts: A theoretical approach. Journal of Public Administration Research and Theory, 26(2), 294-308.

Cheung, Steven N. S. 1998. The Transaction Cost Paradigm - 1998 presidential address Western Economic Association. Economic Inquiry. 36(4): 514-521.

Clemons, Eric K., Sashidhar P. Reddi, and Michael C. Row. 1993. The Impact of Information Technology on the Organization of Economic Activity: The "Move to the Middle" Hypothesis. Journal of Management Information Systems. 10(2): 9-31.

Coase, Ronald. 1937. The nature of the firm. Economica, 4(16): 386-405.

Coase, Ronald. 1960. The Problem of Social Cost. Journal of Law and Economics 3(Oct.): $1-44$.

De Schepper, Steven, Elvira Haezendonck, and Michaël Dooms. 2015. Understanding pre-contractual transaction costs for Public-Private Partnership infrastructure projects. International Journal of Project Management 33(4): 932-946.

Domberger, Simon, and Paul Jensen. Contracting Out by the Public Sector: Theory, Evidence, Prospects. Oxford Review of Economic Policy 13(4): 67-78.

Dyer, Jeffrey H., and Wujin Chu. 2003. The role of trustworthiness in reducing transaction costs and improving performance: Empirical evidence from the United States, Japan, and Korea. Organization Science 14(1): 57-68.

This article is protected by copyright. All rights reserved. 
Girth, Amanda M., Amir Hefetz, Judith M. Johnston, and Mildred E. Warner. 2012. Outsourcing public service delivery: Management responses in noncompetitive markets. Public Administration Review, 72(6): 887-900.

Hefetz, Amir, and Mildred E. Warner. 2012. Contracting or public delivery? The importance of service, market, and management characteristics. Journal of Public Administration Research and Theory 22(2): 289-317.

Joaquin, M. Ernita, and Thomas J. Greitens. 2012. Contract Management Capacity Breakdown? An Analysis of U.S. Local Governments. Public Administration Review 72(6): 807-16.

Johansson, Tobias. 2015. A Critical Appraisal of the Current Use of Transaction Cost Explanations for Government Make-Or-Buy Choices: Towards a Contingent Theory and Forms of Tests. Public Management Review 17(5): 661-678

Johansson, Tobias, and Sven Siverbo. 2011. Governing cooperation hazards of outsourced municipal low contractibility transactions: An exploratory configuration approach. Management Accounting Research 22(4): 292-312.

Johansson, Tobias, Sven Siverbo, and Carolina Camén 2016. Managing cooperation, coordination, and legitimacy: control of contracted public services. Accounting, Auditing \& Accountability Journal 29(6): 1012-1037.

This article is protected by copyright. All rights reserved. 
Johnston, Judith M., and Amanda M. Girth. 2012. Government contracts and "managing the market": exploring the costs of strategic management responses to weak vendor competition. Administration \& Society 44(1): 3-29.

Karjalainen, Katri. 2011. Estimating the cost effects of purchasing centralization: Empirical evidence from framework agreements in the public sector. Journal of Purchasing and Supply Management 17(2): 87-97.

Kauppi, Katri, and Erik M. Van Raaij. 2015. Opportunism and honest incompetence — seeking explanations for noncompliance in public procurement. Journal of Public Administration Research and Theory 25(3): $953-79$.

Langlois, Richard N. 1992. Transaction-cost economics in real time. Industrial and Corporate Change 1(1): 99-127.

Lawther, Wendell. 2002. Contracting for the $21^{\text {st }}$ Century: A Partnership Model. Washington, DC: IBM Center for the Business of Government.

Levin, Jonathan, and Steven Tadelis. 2010. Contracting for government services: Theory and evidence from US cities. The Journal of Industrial Economics 58(3): 507-541.

Li, Huimin, David Arditi, and Zhuofu Wang. 2012. Factors that affect transaction costs in construction projects. Journal of Construction Engineering and Management, 139(1): 60-68.

This article is protected by copyright. All rights reserved. 
Lyons, Bruce R. 1995. Specific investment, economies of scale, and the make-or-buy decision: A test of transaction cost theory. Journal of Economic Behavior \& Organization 26(3): 431-443.

Marsh, Alex. 1998. Local governance: The relevance of transaction cost economics. Local Government Studies 24(1): 1-18.

Marvel, Mary K., and Howard P. Marvel. 2007. Outsourcing oversight: A comparison of monitoring for in-house and contracted services. Public Administration Review 67(3): 521-530.

Mayer, Kyle J., and Nicholas S. Argyres. 2004. Learning to contract: evidence from the personal computer industry. Organization Science 15(4): 394-410.

Melese, Francois, Raymond Franck, Diana Angelis, and John Dillard. 2007. Applying insights from transaction cost economics to improve cost estimates for public sector purchases: The case of US military acquisition. International Public Management Journal 10(4): 357-385.

Milward, H. Brinton, and Keith G. Provan. 1993. The Hollow State: Private provision of public services. In Ingram, H. and Smith, S. R. (eds), Public Policy for Democracy, Washington, D.C.: Brookings, 222-237.

Milward, H. Brinton, and Keith G. Provan. 2000. Governing the Hollow State. Journal of Public Administration Research and Theory 10(2): 359-79. 
Milward, H. Brinton, and Keith G. Provan. 2003. Managing the hollow state.

Collaboration and contracting. Public Management Review 5(1): 1-18.

Mooi, Erik A., and Mrinal Ghosh. 2010. Contract Specificity and Its Performance Implications. Journal of Marketing 74(2): 105-120.

Papke, Leslie E., and Jeffrey Wooldridge. 1996. Econometric methods for fractional response variables with an application to $401(\mathrm{~K})$ plan participation rates. Journal of Applied Econometrics 11(6): 619-32.

Petersen, Ole Helby, Ulf Hjelmar, and Karsten Vrangbæk. 2018. Is contracting out of public services still the great panacea? A systematic review of studies on economic and quality effects from 2000 to 2014. Social Policy \& Administration 52(1): 130157.

Petersen, Ole Helby, Kurt Houlberg, and Lasse Christensen. 2015. Contracting out local services: A tale of technical and social services. Public Administration Review 75(4): $560-570$.

Pilling, Bruce K., Lawrence A. Crosby, and Donald W. Jackson, Jr. 1994. Relational Bonds in Industrial Exchange: An Experiential Test of the Transaction Cost Economic Framework. Journal of Business Research 30(July): 237-51 .

Ramalho, Esmeralda A., Joaquim J.S. Ramalho, and Luís M.S. Coelho. 2018. Exponential Regression of Fractional-Response Fixed-Effects Models with an Application to Firm Capital Structure. Journal of Econometric Methods 7(1): 1-18. 
Faris, Charles W., Patrick J. Robinson, and Yoram Wind. 1967. Industrial buying and creative marketing. Boston: Allyn \& Bacon.

Romzek, Barbara S., and Jocelyn M. Johnston. 2002. Effective Contract Implementation and Management: A Preliminary Model. Journal of Public Administration and Theory 12(3): 423-453.

Sclar, Elliot D. 2000. You Don't Always Get What You Pay For: The Economics of Privatization. Ithaca, NY: Cornell University Press.

Soliño, Antonio Sánchez, and Pilar Gago de Santos. 2010. Transaction costs in transport public-private partnerships: comparing procurement procedures. Transport Reviews 30(3): 389-406.

Van Slyke, David M. 2003. The mythology of privatization in contracting for social services. Public Administration Review 63(3): 296-315.

Van Weele, Arjen. 2014. Purchasing and Supply Chain Management: Analysis, Strategy, Planning and Practice. Andover, MA: Cengage Learning.

Villadsen, A. R., \& Wulff, J. 2018. Fractional Regression Models in Strategic Management Research. In Academy of Management Annual Meeting Best Paper Proceedings.

Whittington, Janice Marie. 2008. The transaction cost economics of highway project delivery: design-build contracting in three states. Doctoral dissertation. University of California, Berkeley, CA.

This article is protected by copyright. All rights reserved. 
Williamson, Oliver E. 1979. Transaction-cost economics: the governance of contractual relations. Journal of law and economics 22(2): 233-261.

Williamson, Oliver E. 1991. Comparative economic organization: The analysis of discrete structural alternatives. Administrative Science Quarterly 36(2): 269-296.

Williamson, Oliver E. 1996. The mechanisms of governance. Oxford: Oxford University Press.

This article is protected by copyright. All rights reserved. 
Figure 1: Transaction attributes, contracting risks, and transaction cost expenditures

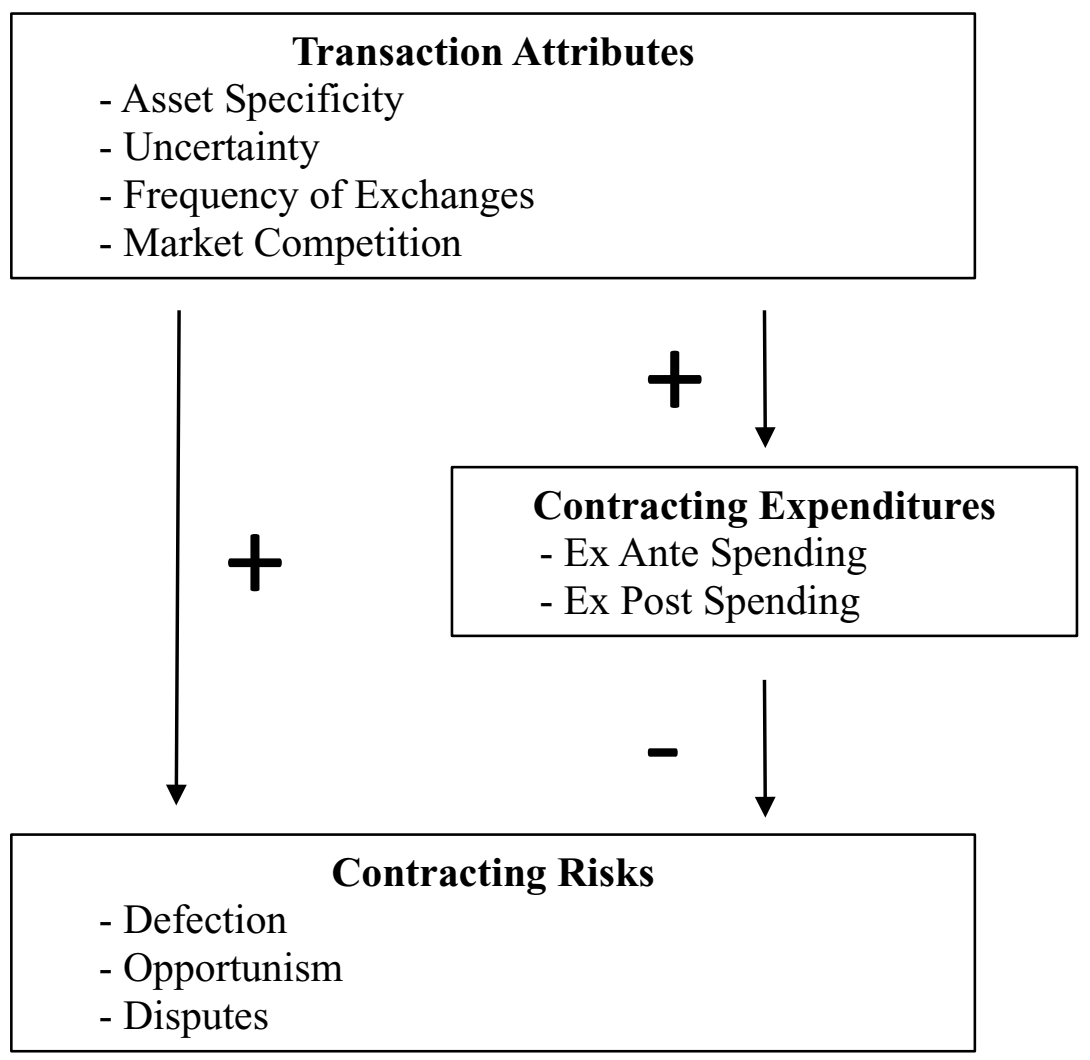

This article is protected by copyright. All rights reserved. 
Table 1 - Examples of Ex Ante and Ex Post Transaction Cost Expenditures

\begin{tabular}{|c|c|c|c|}
\hline \multicolumn{2}{|c|}{ Ex Ante } & \multicolumn{2}{|c|}{ Ex Post } \\
\hline Search & Negotiation & Monitoring & Enforcement \\
\hline - Scanning the & - Evaluating & - Developing & - Executing \\
\hline market for & formal bids & performance & contract \\
\hline potential & - Conducting & metrics & options or \\
\hline vendors & reference & - Gathering & termination \\
\hline - Developing & checks of & information from & - Implementing \\
\hline product & proposers & product users & performance \\
\hline requirements & - Negotiating & and other & incentives \\
\hline and & contract terms & stakeholders & - Resolving \\
\hline specifications & (e.g. method of & - Assessing & disputes \\
\hline - Incentivizing or & compensation) & deliverables & (negotiation, \\
\hline training & & & arbitration, \\
\hline potential & & & litigation) \\
\hline bidders & & & \\
\hline
\end{tabular}

This article is protected by copyright. All rights reserved. 
Figure 2 - Ex-ante transaction cost spending as a percentage of contract value for 22 local government services

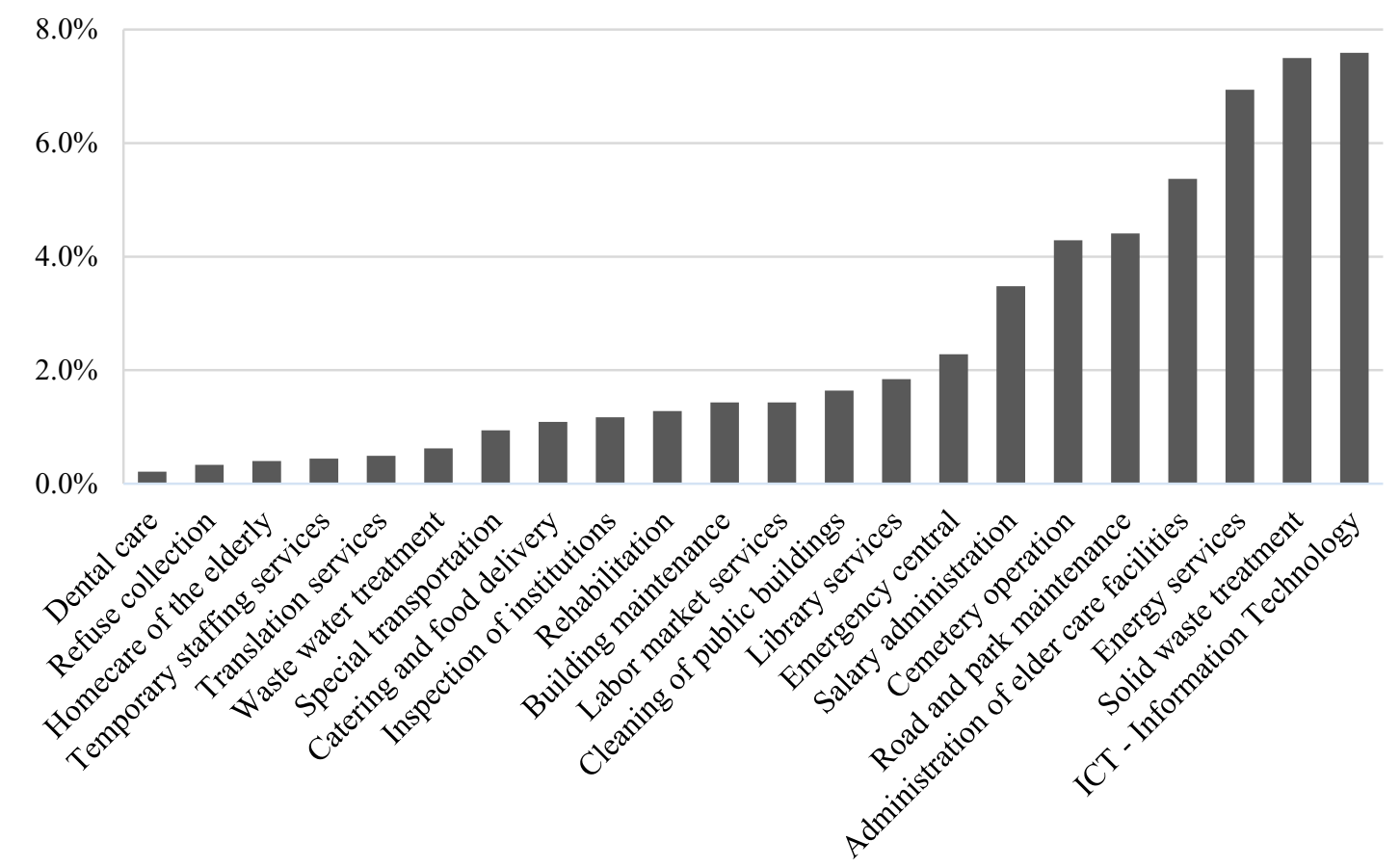

Source: Sample of 72 contracts issued by 47 Danish local governments for 22 goods and services with varying contracting complexity.

This article is protected by copyright. All rights reserved. 
Table 2 - Descriptive Statistics

\begin{tabular}{|c|c|c|c|c|}
\hline Variable & Mean & Std. Dev. & Min & Max \\
\hline \multicolumn{5}{|l|}{ Dependent Variable } \\
\hline $\begin{array}{l}\text { Ex Ante Transaction Cost Expenditure } \\
\text { (percent of contract size) }\end{array}$ & 2.66 & 5.04 & 0.04 & 36.00 \\
\hline \multicolumn{5}{|l|}{ Independent and Control Variables } \\
\hline Product Complexity (scale of $1-5,1=$ very & 3.20 & 0.47 & 2.62 & 4.13 \\
\hline \multicolumn{5}{|l|}{ easy, $5=$ very difficult) } \\
\hline Management Capacity (administrative & 14.95 & 1.23 & 12.20 & 19.20 \\
\hline \multicolumn{5}{|l|}{ staff/1000 inhabitants) } \\
\hline $\begin{array}{l}\text { Fiscal Capacity (tax base per inhabitant, } \\
\text { thousand Danish Kroner) }\end{array}$ & 183.65 & 27.53 & 151.42 & 274.41 \\
\hline \multicolumn{5}{|l|}{ Contracting Experience (dummy, $0=$ service } \\
\hline \multicolumn{5}{|l|}{ not contracted before, $1=$ service contracted } \\
\hline before) & 0.44 & 0.50 & 0.00 & 1.00 \\
\hline \multicolumn{5}{|l|}{ Government Contracting Percentage (level of } \\
\hline private purchases in $\%$ of total service & & & & \\
\hline spending) & 27.40 & 3.78 & 21.10 & 44.20 \\
\hline Contract Value (million Danish Kroner) & 31.27 & 38.55 & .24 & 159.92 \\
\hline
\end{tabular}


Population (thousand inhabitants)

Note: $\mathrm{N}=72$ local government contracts. 
Table 3 - Fractional Response Regression of Impact of Independent Variables and Controls on Ex Ante Transaction Cost Expenditure Percentage

\begin{tabular}{|c|c|c|c|}
\hline Variable & $\begin{array}{c}\text { Coefficient } \\
\text { (Standard } \\
\text { Errors) }\end{array}$ & $\begin{array}{c}95 \text { Percent } \\
\text { Confidence } \\
\text { Interval }\end{array}$ & $\begin{array}{l}\text { Average Marginal } \\
\text { Effects (percentage } \\
\text { point change in } \\
\text { government ex ante } \\
\text { transaction costs) }\end{array}$ \\
\hline \multicolumn{4}{|l|}{ Independent Variables } \\
\hline Product Complexity & $.604(0.301)^{*}$ & $.014-1.195$ & 1.51 \\
\hline Management Capacity & $.241(0.233)$ & $-.215-.697$ & 0.60 \\
\hline Fiscal Capacity & $.022(0.010)^{*}$ & $.002-.043$ & 0.06 \\
\hline Contracting Experience & $-.753(0.217)^{* * *}$ & $-1.178--.329$ & -1.89 \\
\hline Government Contracting & $-.030(0.034)$ & $-.0979-.036$ & -0.08 \\
\hline \multicolumn{4}{|l|}{ Percentage } \\
\hline Contract Value & $-.034(0.006)^{* * *}$ & $-.0451--.0222$ & -0.08 \\
\hline \multicolumn{4}{|l|}{ Control } \\
\hline Population & $0.001(0.001)$ & $-.001-.003$ & 0.00 \\
\hline Constant & $-11.879(5.727)^{*}$ & $-23.103--.655$ & \\
\hline $\mathrm{N}$ & 72 & & \\
\hline Pseudo $\mathrm{R}^{2}$ & 0.114 & & \\
\hline
\end{tabular}

This article is protected by copyright. All rights reserved. 
Log pseudolikelihood

Deviance

Pearson
$-6.169827695$

1.620881611

1.798681975

Notes: Robust standard errors in parentheses (clustered at the 22 services).

${ }^{*} p<0.05,{ }^{* *} p<0.01,{ }^{* * *} p<0.001$. 


\section{Appendix 1: Data sources}

The analysis builds on an original dataset of 72 cases documenting the ex-ante transaction costs of local government contracting. These data come from a database of public contracts made available by Local Governments Denmark, a non-profit organization owned by the 98 municipalities in the country, and the Danish central government. The database contains information about 159 public contracts that we manually collected to build our dataset. In 79 of the 159 contracts, governments were able to provide a precise monetary measure of the contract price and ex ante transaction cost expenditures, which is the information we need to calculate our dependent variable. The fact that around half of governments were not able to provide an exact estimate of their transaction cost expenditure is not surprising, as local governments do not have a standard accounting system for registering their transaction costs.

Of the 79 contracts with full information on governments' ex ante transaction costs, 72 contracts concerned purchases made by local governments, whereas 7 contracts concerned a central government organization, a state-owned public organization or one of the 5 Danish regions. Due to comparability in our statistical analysis, we dropped the 7 cases that did not concern local government contracts, meaning that our sample of 72 contracts represents all local government contracts in the database where purchasing authorities were able to provide exact information necessary to calculate our dependent 
variable. The 72 contracts were reported by 47 out of the 98 Danish local governments: 30 governments reporting on one contract, 11 governments reporting on two contracts, four governments reporting on three contracts, and two governments reporting on four contracts. Assignment of municipalities to the database was voluntary, meaning that the sample is not a randomly drawn sample of local government contracts. Generalization to the population of all government contracts should thus be made with caution.

The database utilizes a written template that instructs officials how to register contract information and calculate contract costs. Before a contract is included in the database, procurement staff working in Local Governments Denmark scrutinize the record to check that all information is accurate and in compliance with the template. This helps insure the validity of the data. Each database entry contains information about the contracting government, the product being contracted, the local government's experience with contracting for the product, the monetary value and duration of the contract, along with a brief narrative description. Furthermore, the local governments were asked a series of questions about the contract value and the contracting process, including the amount their government spent to prepare the tender, identify vendors, negotiate terms, and sign the final contract. This provides the means to calculate ex ante transaction costs.

The sample of contracts cover 22 different product categories that capture a diversity of goods and services that Danish local governments commonly purchase. Table Al lists the product categories included in our analysis. 
Table A1: Product Categories

Administration of Elder Care Facilities

Inspection of Institutions

Building Maintenance

Labor Market Services

Catering and Food Delivery

Library Services

Cemetery Operations

Refuse Collection

Cleaning of Public Buildings

Rehabilitation Services

Dental Care

Road and Park Maintenance

Driving/Special Transportation

Salary administration

Emergency Services

Temporary Staffing Services

Energy Services

Translation Services

Homecare of the Elderly

Solid Waste Treatment

Information Technology Systems

Waste Water Treatment

Source: Dataset of 72 local government contracts.

This article is protected by copyright. All rights reserved. 


\section{Appendix 2: Transaction Cost Survey of Local Danish Municipal Managers}

We conducted a survey of 42 local contract managers, asking them to rate the contracting difficulty of the 22 services in our sample of local government contracts on a five-point scale ranging from "easy" to "difficult". For each of the 22 services, the respondents were asked to rank the service on the five-point scale. The survey was formulated in Danish. Below, we provide a translated version of the question wording (authors' translation).

\section{Introduction text}

Some tasks are easier or more difficult to describe than others. How easy or difficult do you think it is for a public buyer to write the product requirements, carry out the tender and write a contract that unambiguously describes how the supplier should solve the task?

Please provide your best estimate for the following products, regardless of whether you have specific experience of procuring the particular product.

\section{Question formulation}

How easy or difficult is it for a public buyer to write the product requirements, carry out the tender and write a contract that unambiguously describes how the supplier should solve the task? 
22 products listed, as seen in Table A1.

This article is protected by copyright. All rights reserved. 


\section{Appendix 3: Correlations}

Table A2: Correlations for Independent and Control Variables and Dependent Variable

\begin{tabular}{|c|c|c|c|c|c|c|c|c|}
\hline & $\begin{array}{c}\text { Product } \\
\text { Complexity }\end{array}$ & $\begin{array}{c}\text { Management } \\
\text { Capacity }\end{array}$ & $\begin{array}{c}\text { Fiscal } \\
\text { Capacity }\end{array}$ & $\begin{array}{l}\text { Contracting } \\
\text { Experience }\end{array}$ & $\begin{array}{l}\text { Government } \\
\text { Contracting } \\
\text { Percentage }\end{array}$ & $\begin{array}{l}\text { Contract } \\
\text { Value }\end{array}$ & Population & $\begin{array}{c}\text { Ex ante } \\
\text { transaction } \\
\text { cost } \\
\text { expenditure }\end{array}$ \\
\hline Product Complexity & 1.000 & & & & & & & \\
\hline Management Capacity & 0.1072 & 1.000 & & & & & & \\
\hline Fiscal Capacity & 0.0202 & -0.4658 & 1.000 & & & & & \\
\hline $\begin{array}{l}\text { Contracting } \\
\text { Experience }\end{array}$ & -0.2455 & -0.0596 & 0.0512 & 1.000 & & & & \\
\hline $\begin{array}{l}\text { Government } \\
\text { Contracting } \\
\text { Percentage }\end{array}$ & 0.0242 & -0.3176 & 0.1304 & -0.0586 & 1.000 & & & \\
\hline Contract Value & -0.1434 & -0.1601 & 0.2794 & 0.0256 & 0.0840 & 1.000 & & \\
\hline Population & 0.1265 & 0.3041 & -0.0604 & -0.0577 & -0.2804 & -0.0544 & 1.000 & \\
\hline $\begin{array}{l}\text { Ex ante transaction } \\
\text { cost expenditures }\end{array}$ & 0.2358 & 0.1649 & 0.0743 & -0.2005 & -0.1636 & -0.2952 & 0.1897 & 1.000 \\
\hline
\end{tabular}

\section{Endnotes}

\footnotetext{
${ }^{1}$ Studies of actual transaction costs expenditures are rare even in business-to-business contracting scholarship where the transaction cost literature originates

(Pilling, Crosby and Jackson 1994; Barthélemy and Quélin 2006; Mooi and Ghosh 2010).
} 
${ }^{2}$ We use the generic term "product" to refer to both goods and services.

${ }^{3}$ In this article, we focus on transaction attributes that impact the behavior of the two parties to the exchange and ultimately the transaction cost expenditures required to mitigate the contracting risk. There are other transaction cost attributes that influence transaction cost expenditures, for example bulk purchasing may lower per unit administrative costs.

${ }^{4}$ Here we use risk as a "cost" to mean the probability that a negative event happens multiplied by the value lost should that event happen.

${ }^{5}$ It is important to highlight that our presumption is that a government has chosen to "buy" rather than "make" a product. Internal production can also come with expenditures analogous to transaction costs, such 
as hiring employees, monitoring their behavior, evaluating their performance. Williamson (1981) calls these "governance costs." In making the decision to make or buy a product, a government can weigh both the production costs and the transaction costs of external versus internal production. Here we focus on the transaction costs associated with government buying, as previous research on this issue has been particularly scarce.

${ }^{6}$ While we leave this effect aside in the present analysis, another consequence of experience for contractual relationships can be greater trust, which is likely lower transaction costs over time. Experience builds reputations among buyers and sellers. Reputations for trustworthiness can decrease transaction costs on both sides of the transactional relationship (Dyer and Chu 2003), e.g., by reducing demands for guarantees, complex contracts, and detailed monitoring.

${ }^{7}$ Thirty governments reporting on one contract, 11 governments reporting on two contracts, four governments reporting on three contracts, and two governments reporting on four contracts. There are 98 local governments in Denmark, meaning that our sample represents just around half. Because they were collected by local government procurement officials, the data and coding were informed by professional expertise and knowledge. However, we are unaware of a means for otherwise assessing the data quality. Moreover, the collection procedures and data were not reviewed by a quality assurance authority, such as Statistics Denmark. Finally, the sample is non-random because it was voluntary for local governments to report cases to the database.

${ }^{8}$ Because of the fractional nature of our dependent variable, we implement the analysis using the fractional logit regression specification in Stata version 15.1 and specify the family as binomial and link as logit. All models include robust standard errors clustered at the 22 services. As a robustness test, we run models with robust standard errors clustered at the 47 municipalities and find no significant differences (not shown, can be obtained from the authors). 
${ }^{9}$ To implement this specification, we specify our fractional regression model as explained in the methods section and calculate the marginal effects by using the margins, $d y d x\left(^{*}\right)$ command in Stata 15.1. 


\section{University Library}

\section{- M M N E R VA A gateway to Melbourne's research publications}

Minerva Access is the Institutional Repository of The University of Melbourne

Author/s:

Petersen, OH;Baekkeskov, E;Potoski, M;Brown, TL

Title:

Measuring and Managing Ex Ante Transaction Costs in Public Sector Contracting

Date:

2019-09-01

Citation:

Petersen, O. H., Baekkeskov, E., Potoski, M. \& Brown, T. L. (2019). Measuring and Managing Ex Ante Transaction Costs in Public Sector Contracting. PUBLIC ADMINISTRATION REVIEW, 79 (5), pp.641-650. https://doi.org/10.1111/puar.13048.

Persistent Link:

http://hdl.handle.net/11343/286852 